\title{
Response of Different Levels of NPK, Zinc and Neem Cake on Soil Health Growth and Yield of Maize (Zea mays L.)Var. Ganga 101
}

\author{
Sonu Singh*, Arun Alfred David and Tarence Thomas
}

\author{
Department of Soil Science and Agricultural Chemistry, Sam Higginbottom University of \\ Agriculture, Technology and Sciences- 211007 SHUATS Allahabad, U.P., India \\ *Corresponding author
}

\begin{abstract}
A B S T R A C T
An experiment was conducted during rabi season 2016-17 on crop research farm of department of Soil Science and Agricultural Chemistry, Naini Agricultural Institute, SHUATS, Allahabad. It may be concluded from trial that the different levels of NPK, Zinc

Keywords

Zinc, Neem cake,

NPK, Soil

properties and

Maize.

Article Info

Accepted:

04 June 2017

Available Online:

10 July 2017 and Neem cake in the experiment gave highest value. The maximum bulk density $\left(\mathrm{g} \mathrm{cm}^{-3}\right)$ was recorded in the treatment combination of $\mathrm{T}_{2}$ [NPK@0\%, Zinc@50\% NSC@0\%], the maximum particle density $\left(\mathrm{g} \mathrm{cm}^{-3}\right)$ was recorded in the treatment combination of $\mathrm{T}_{11}$ [NPK@100\% Zinc@50\% NSC@50\%], pore space $(\%)$ in the treatment combination of $\mathrm{T}_{11}$ [NPK@100\%, Zinc@50\%, NSC@50\%], solid space (\%) in the treatment combination of $\mathrm{T}_{9}$ [NPK@100\%,ZINC@0\%, NSC@50\%] and water retaining capacity (\%) was recorded in treatment combination of $\mathrm{T}_{11}$ [NPK@100\%, Zinc@50\%, NSC@ 50\%], was found to be the best for improvement of physical properties of soil with the level of NPK, Zinc and Neem cake in the experiment gave highest yield. The maximum $\mathrm{pH}$ was recorded in $\mathrm{T}_{8}$ [NPK@100\%, Zinc@0\%, NSC@0\%]. Maximum EC $\left(\mathrm{dSm}^{-1}\right)$ was recorded in the treatment combination of $\mathrm{T}_{9}$ [NPK@100\%, Zinc@0\%, NSC@50\%] and organic carbon (\%) was also recorded. The available nitrogen $\left(\mathrm{kg} \mathrm{ha}^{-1}\right)$, phosphorus $\left(\mathrm{kg} \mathrm{ha}^{-1}\right)$, potassium $\left(\mathrm{kg} \mathrm{ha}^{-1}\right)$ and zinc (ppm) with the treatment combination of $\mathrm{T}_{11}$ [NPK@100\%, Zinc@50\%, NSC@50\%], respectively was found to be the best for the improvement soil chemical properties due to integrated nutrient management. Therefore, farmer of Allahabad region can adopt this combination to give the highest yield of Maize.
\end{abstract}

\section{Introduction}

Maize (Zea mays L.) is the third most cereal crop in Asia as well as in India. It is grown successfully in warm temperate region as well as in the humid and sub-tropical zones and is also cultivated in tropic. Maize production holds a special position historically, agronomically and commercially. It is used as food, feed and fodder and now a days it is gaining immense importance on account of its potential uses in manufacturing starch, plastic, rayon, adhesive, dye, resins, boot polish, syrups ethanol etc. It is a miracle crop and has very potentiality, there is no cereal on the earth which has so immense potentiality and that is why it is called "queen of cereals". In India, the major states in which this crop is cultivated are Gujarat, Rajasthan, Punjab, Haryana, Madhya Pradesh, Uttar Pradesh, Himachal Pradesh and Bihar. Maize is grown in an area of 8.49 million hectares, with production of 21.28 million tones and productivity of $2507 \mathrm{~kg} \mathrm{ha}^{-1}$. Maize has been 
about 4500 year old even earlier in origin. Pooler grains of Zeatripsocum are said to have been found at a depth of more than fifty meters under Mexico City (Weather wax and Randolph, 1965).

Maize (Zea mays L.) has becoming very popular cereal crop in India because of the increasing market price and high production potential of hybrid varieties in both irrigated as well as rain fed conditions. More ever in irrigated areas farmers produce the income equal to the cash crops such as sugarcane, onion, cotton, etc. in comparatively short time period of 120-130 days by cultivating hybrid maize varieties. Hence the trend of replacing some cash crops with maize in intensive cultivation is observed in present condition. (Kimdu et al., 2009).

The organic sources besides supplying $\mathrm{N}, \mathrm{P}$ and $\mathrm{K}$ also make unavailable sources of elemental nitrogen, bound phosphates, micronutrients, and decomposed plant residues into an available form to facilitate to plant to absorb the nutrients. But, it is also the fact that optimum yield level of maize production can't be achieved by using only organic manures because of their low nutrient content. Efficacy of organic sources to meet the nutrient requirement of crop is not as assured as mineral fertilizers, but the joint use of chemical fertilizers along with various organic sources is capable of improving soil quality and higher crop productivity on longterm basis. Highest productivity of crops in sustainable manner without deteriorating the soil and other natural resources could be achieved only by applying appropriate combination of different organic manures and inorganic fertilizers (Chandrashekara et al., 2000).

Nitrogen is the most deficient primary nutrient in Indian soil and varies from state to state (Srikanth et al., 2009).
Nitrogen is a vitally important for plant nutrient. Nitrogen is essential constituent of protein and is present in many other compound of great physiological importance in plant metabolism. Nitrogen is called a basic constituent of life. Nitrogen also impart vigorous vegetative growth dark green colour to plant and it produce early growth of maize. Nitrogen governs the utilization of potassium, phosphorus and other elements in maize crop (Singh et al., 2010).

Phosphorus has a great role in energy storage and transfer and closely related to cell division and development of maize. Phosphorus is a constituent of nucleic acid, and phospho-lipid. Phosphorus compound act as "energy currency" within plants phosphorus is essential for transformation of energy, in carbohydrate metabolism, in fat metabolism, in respiration of plant and early maturity of maize (Singh et al., 2010).

Potassium play important role in formation of protein and chlorophyll and it provide much of osmotic "pull" that draw water into plant roots. Potassium produces strong stiff straw in maize and reduces lodging in maize. Potassium imparts increase vigour and disease resistance to plant (Singh et al., 2010).

Zinc play important role in the correct functioning of many enzyme systems, the synthesis of nucleic acids and auxins (plant hormones) metabolisms, protein analysis and normal crop development and growth (Mengel and Kirkby, 1982, Havlinn et al., 2006). Phosphorus and Zinc, though essential for plant growth, are antagonistic to each other in certain circumstances, such as when $\mathrm{P}$ is supplied in high levels and $\mathrm{Zn}$ uptake becomes slower or inadequate (Mengel and Kirkby, 1979). This may be as a result of slower rate of translocation of $\mathrm{Zn}$ from roots to tops, i.e. zinc accumulation in the roots and lower $\mathrm{Zn}$ uptake. Plants absorb $\mathrm{Zn}$ in the form 
of $\mathrm{Zn}$. The functional role of $\mathrm{Zn}$ includes auxins metabolism, nitrogen metabolism, influence on the activities of enzymes, cytochrome synthesis and stabilization of ribosomal fractions and protection of cells against oxidative stress (Tisdale et al., 1997).

Neem (Azadiractes indica) is a very useful tree on has emcee importance in our daily life as well as in agriculture. Neem seed cake which is a residue optioned after oil extraction from the seed of neem tree act as a biofertilizer when applied in the field. Neem seed cake has quite distinct chemical properties having organic carbon, $\mathrm{N}$ and $\mathrm{P}$ contents in high amount and also provides other nutrient such as $\mathrm{K}, \mathrm{Ca}, \mathrm{Mg}$ and other micronutrient which indicate its potential for nutrient supply for crop growth. The organic matter in Neem seed cake $\left(646.64 \mathrm{~kg}^{-1}\right)$, suggested the ability of Neem seed cake to improve the physical, chemical and biological properties in the soil (Garba and Oyinlola, 2014).

\section{Materials and Methods}

The experiment was conducted during rabi season 2016-17 on crop research farm of Department of Soil Science and Agricultural Chemistry, Naini Agricultural Institute, SHUATS Allahabad. The area is situated on the south of Allahabad on the right side of the river Yamuna on the South of Rewa road at a distance of about $6 \mathrm{~km}$ from Allahabad city. It is situated at $25022^{\prime} 45.14 " \mathrm{~N}$ latitude 810 54'49.95" E longitude and at the altitude of 98 meter above the sea level (MSL). The treatment consisted of different levels of NPK, Zinc, NSC, T 0 [NPK@0\% + Zinc@0\% $+\quad \mathrm{NSC} 0 \%$ Control, $\quad \mathrm{T}_{1}[\mathrm{NPK} @ 0 \%+$ Zinc@0\% + NSC@50\%], T2 $[$ NPK@0\% + Zinc@50\% + NSC@0\%], T 3 [NPK@0\% + Zinc@50\% + NSC@50\%], T4 $[$ NPK@50+ Zinc@0\% + NSC@0\%], T5 $[$ NPK@50\% + Zinc@0\% + NSC@50\%], T6 $[$ NOK@50\% + Zinc@50\% + NSC@0\%], T7 7 NPK@50\% +
Zinc@50\%+NSC@50\%], T8 $[$ NPK@100\%+ Zinc@0\% + NSC@0\%],T9 [NPK@100\% + Zinc@0\% + NSC@50\%], T 10 [NPK@100\%+ Zinc@50\% + NSC@0\%], T11 $[$ NPK@100\% + Zinc@50\% + NSC@50\%].The trial was laid out in a factorial randomized block design with three replication; plot size was $2 \times 2 \mathrm{~m}$ for crop seed rate is $20-25 \mathrm{~kg} \mathrm{ha}^{-1}$ (Zea mays L.) Cv. Ganga-101. Applies the recommended dose of nitrogen, phosphorus and potassium with source of Urea, SSP, MOP, respectively, basal dose of fertilizer was applied and Zinc and Neem seed cake applies in respective plots according to treatment. All the agronomic practices were carried out uniformly to raise the crop. Soil samples were collected from the soil $0-15 \mathrm{~cm}$ depth, air dried kept in an oven at $105^{\circ} \mathrm{C}$ for $48 \mathrm{hrs}$. for drying, pass through $2 \mathrm{~mm}$ sieve, soils were analysis by using standard procedures as described for physical bulk density $\left(\mathrm{g} \mathrm{cm}^{-3}\right)$, particle density $\left(\mathrm{g} \mathrm{cm}^{-3}\right)$, pore space $(\%)$ and water holding capacity (\%) (Muthuaval, 1992) and Soil texture (Bouyoucous, 1927). For chemical pH 1:2 (w/v) (Jackson, 1958), EC $\left(\mathrm{dSm}^{-1}\right)$ (Wilcox, 1950), organic carbon (\%) (Walkley, and Black, 1947), available nitrogen $\mathrm{kg} \mathrm{ha}^{-1}$ (Subbiah and Asija, 1956), phosphors $\mathrm{kg} \mathrm{ha}^{-1}$ (Olsen et al., 1954) and potassium kg ha ${ }^{-1}$ (Toth and Price, 1949) and available zinc kg ha ${ }^{-1}$ (Shaw and Dean, 1952).

\section{Results and Discussion}

The results given in table 1 indicate some of the important parameter on chemical properties on maize crop different treatment of NPK, zinc and Neem cake, bulk density ( $\mathrm{g}$ $\left.\mathrm{cm}^{-3}\right)$, particle density $\left(\mathrm{g} \mathrm{cm}^{-3}\right)$, pore space (\%) was found non-significant and solid space $(\%)$, water retaining capacity (\%) was found significant. Bulk density $\left(\mathrm{g} \mathrm{cm}^{-3}\right)$ (Fig. 1), particle density $\left(\mathrm{g} \mathrm{cm}^{-3}\right)$, pore space $(\%)$ was recorded as 1.19, 2.83 and 52.60 respectively in the treatment that was non- significantly higher as compared to other treatment 
combination. Solid space (\%), Water retaining capacity (\%) was recorded as 47.30 and $\mathbf{5 7 . 2 3}$ in the significantly higher as compared to other treatment combination.

The results given in table 2 indicate some of the important parameter on chemical properties on maize crop different treatment of NPK, Zinc and Neem cake, pH and EC $\left(\mathrm{dSm}^{-1}\right)$ was found non-significant and organic carbon (\%), available nitrogen $\left(\mathrm{kg} \mathrm{ha}{ }^{-1}\right)$, phosphorus $\left(\mathrm{kg} \mathrm{ha}^{-1}\right)$, potassium $\left(\mathrm{kg} \mathrm{ha}^{-1}\right)$ and zinc (ppm) was found significant. Organic carbon (\%), available nitrogen $\left(\mathrm{kg} \mathrm{ha}^{-1}\right)$, phosphorus $\left(\mathrm{kg} \mathrm{ha}^{-1}\right)$, potassium $\left(\mathrm{kg} \mathrm{ha}^{-1}\right)$ and zinc (ppm) was recorded as $0.70,350.56$, $35.61,240.25$ and 1.61 respectively in the treatment that was significantly higher as compared to other treatment combination. $\mathrm{pH}$ and EC was recorded as 5.74 and $0.20\left(\mathrm{dSm}^{-1}\right)$ in the non-significantly higher as compared to other treatment combination (Figs. 2-8).

Fig.1 Bulk density of soil (Post-harvest)

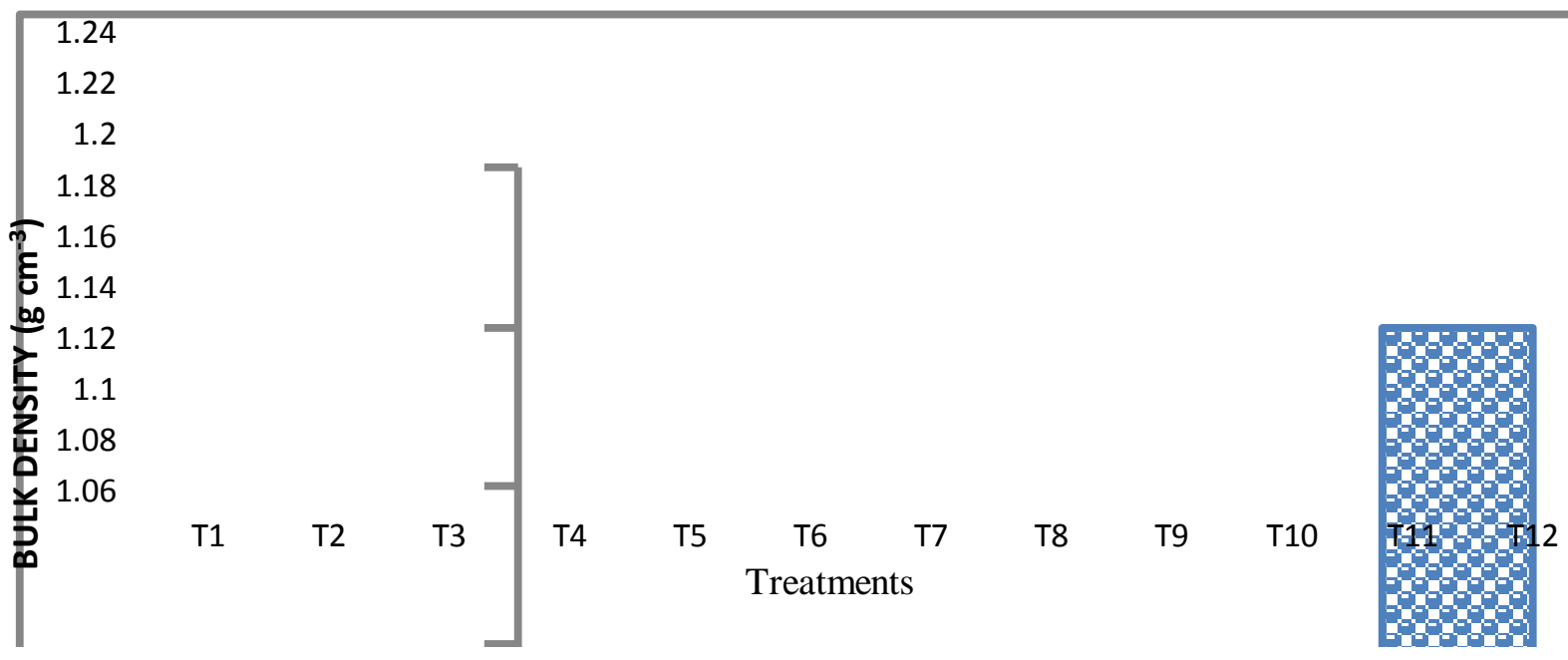

Fig.2 pH of soil (Post-harvest)

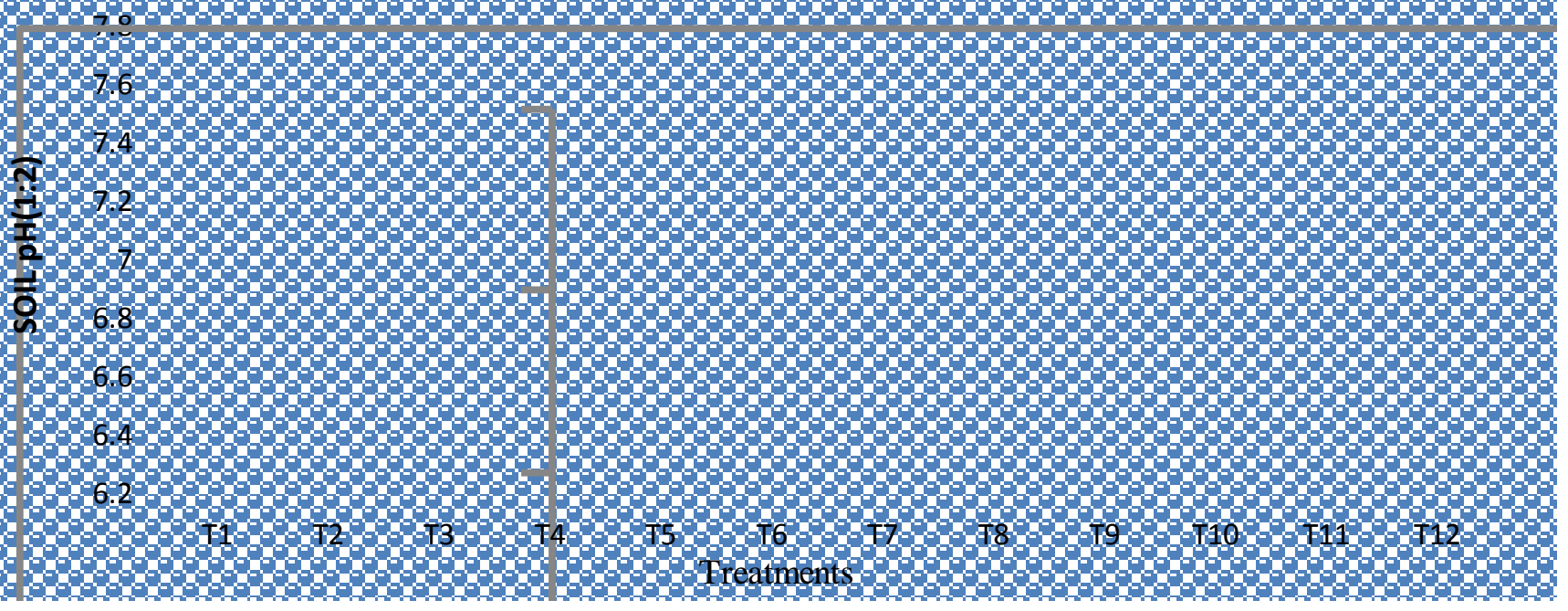


Fig.3 EC (dS m$\left.{ }^{-1}\right)$ of soil (Post-harvest)

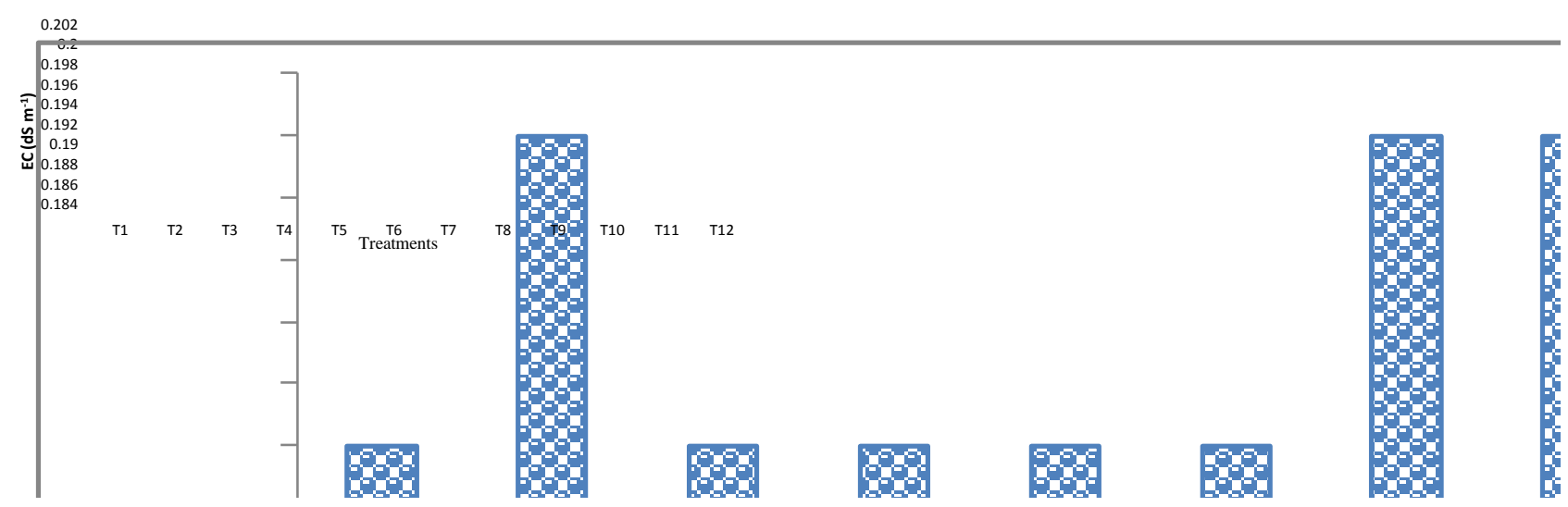

Fig.4 OC (\%) of soil (Post-harvest)

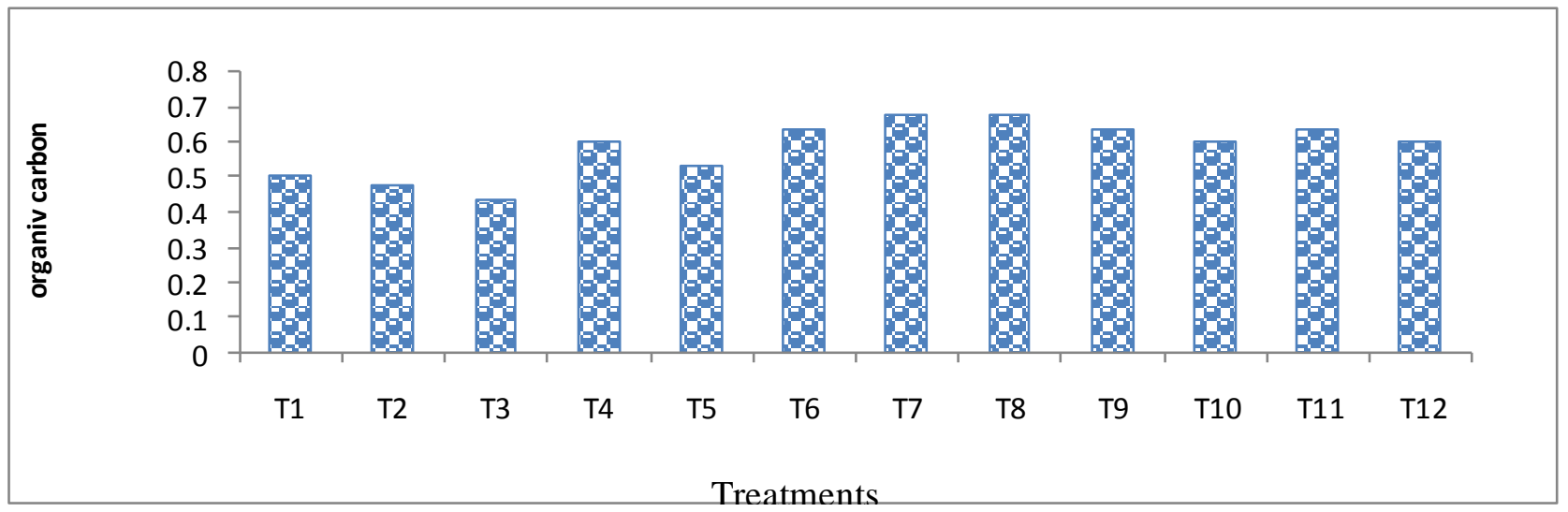

Fig.5 Available nitrogen $\left(\mathrm{kg} \mathrm{ha}^{-1}\right)$ of soil (Post-harvest)

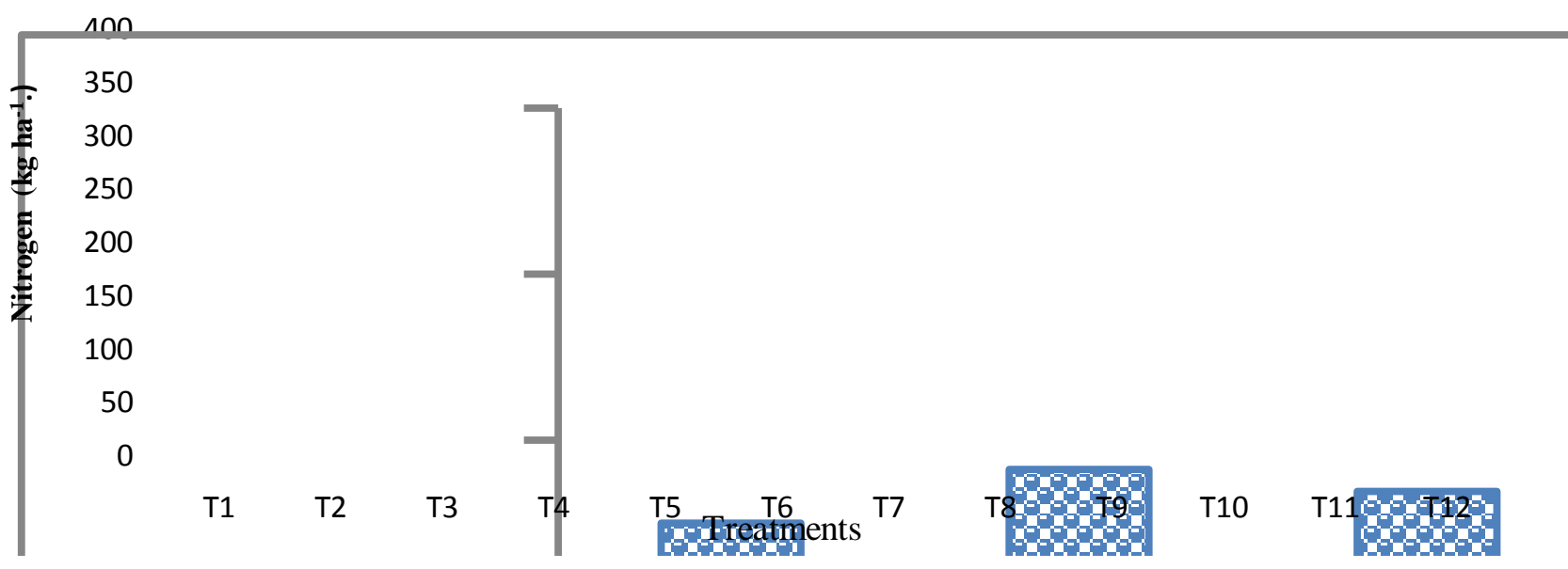


Fig.6 Available phosphorus ( $\mathrm{kg}$ ha ${ }^{-1}$ ) of soil (Post-harvest)

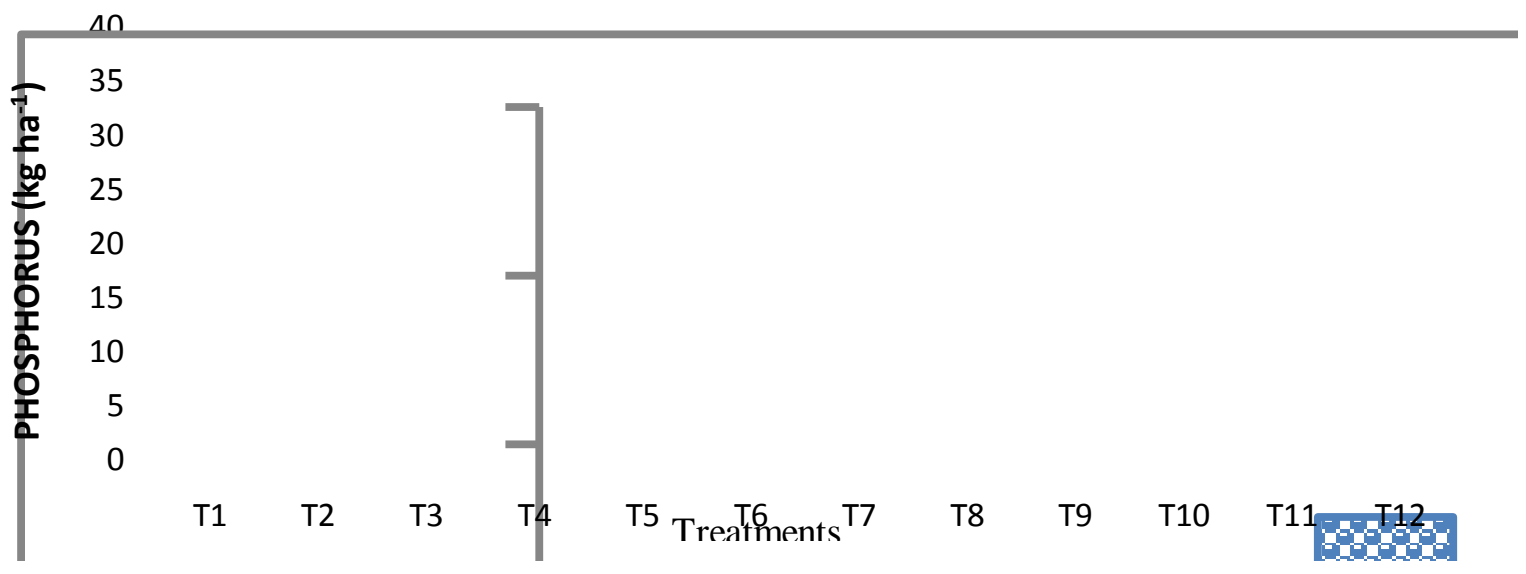

Fig.7 Available potassium ( $\left.\mathrm{kg} \mathrm{ha}^{-1}\right)$ of soil (Post-harvest)

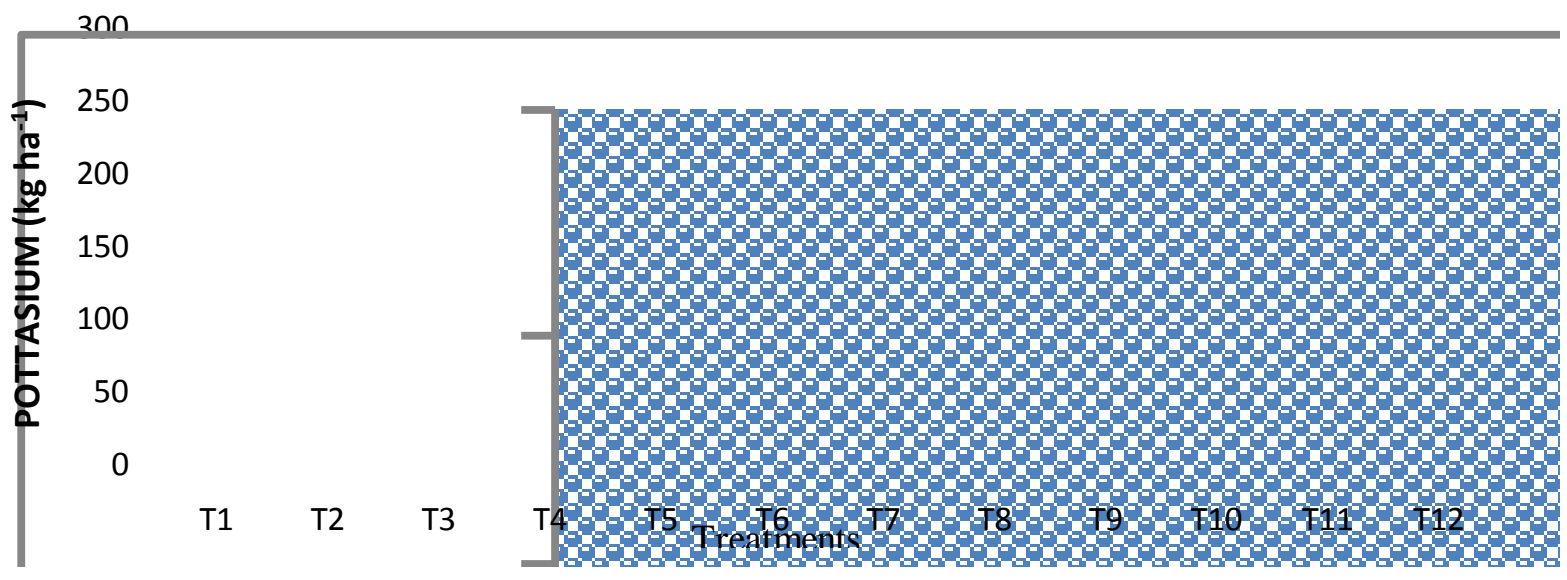

Fig.8 Available zinc (ppm) of soil (Post-harvest)

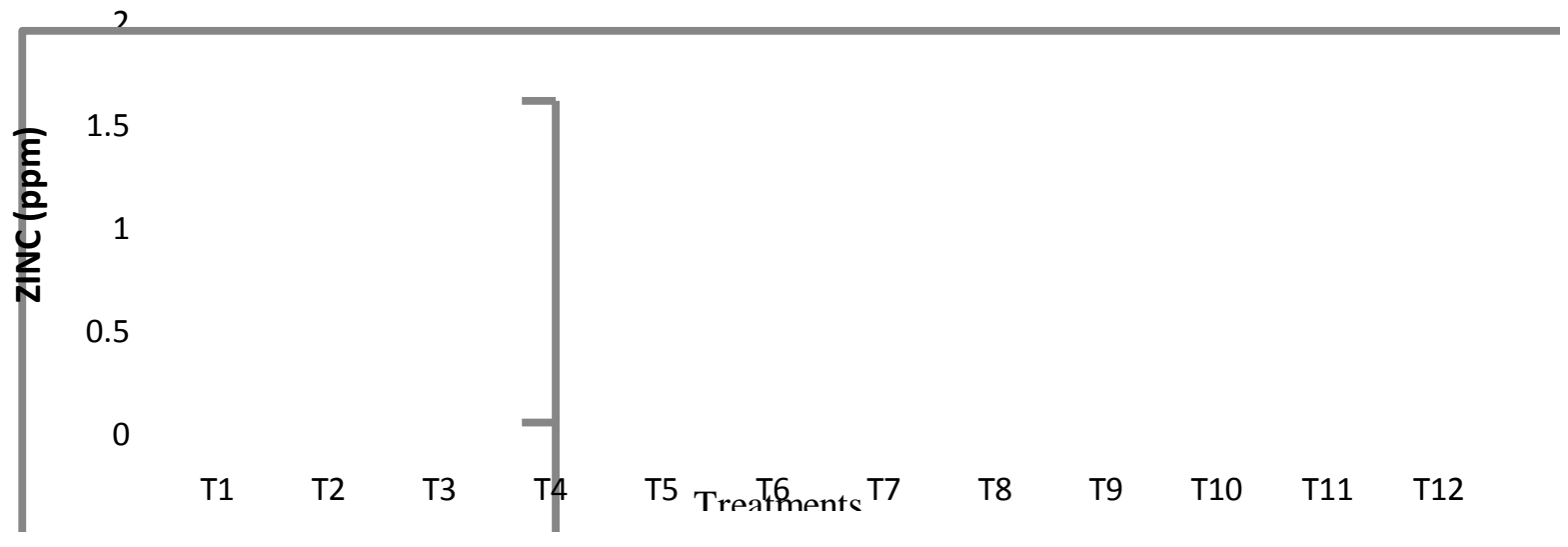


Table.1 Effect of different levels of NPK, Zinc and NSC on soils chemical properties after harvest Maize crop

\begin{tabular}{|l|l|l|l|l|l|}
\hline Treatment & $\begin{array}{l}\text { Bulk density } \\
\left(\mathbf{g ~ c m}^{-3}\right)\end{array}$ & $\begin{array}{l}\text { Particle } \\
\text { density } \\
\left(\mathbf{g} \mathbf{~ c m}^{-3}\right)\end{array}$ & $\begin{array}{l}\text { Pore space } \\
(\mathbf{\%})\end{array}$ & $\begin{array}{l}\text { Solid space } \\
(\boldsymbol{\%})\end{array}$ & $\begin{array}{l}\text { Water } \\
\text { retaining } \\
\text { capacity }(\%)\end{array}$ \\
\hline $\mathbf{T}_{\mathbf{0}}$ & 1.15 & 2.30 & 48.00 & 52.00 & 56.72 \\
\hline $\mathbf{T}_{\mathbf{1}}$ & 1.14 & 2.50 & 47.33 & 52.66 & 54.12 \\
\hline $\mathbf{T}_{\mathbf{2}}$ & 1.22 & 2.37 & 47.33 & 49.33 & 54.15 \\
\hline $\mathbf{T}_{\mathbf{3}}$ & 1.18 & 2.36 & 48.33 & 51.66 & 49.82 \\
\hline $\mathbf{T}_{\mathbf{4}}$ & 1.19 & 2.46 & 50.00 & 50.00 & 56.90 \\
\hline $\mathbf{T}_{\mathbf{5}}$ & 1.18 & 2.33 & 50.66 & 49.33 & 50.41 \\
\hline $\mathbf{T}_{\mathbf{6}}$ & 1.15 & 2.14 & 47.33 & 52.66 & 53.15 \\
\hline $\mathbf{T}_{\mathbf{7}}$ & 1.12 & 2.2 & 48.66 & 51.33 & 52.18 \\
\hline $\mathbf{T}_{\mathbf{8}}$ & 1.17 & 2.34 & 49.00 & 41.00 & 59.55 \\
\hline $\mathbf{T}_{\mathbf{9}}$ & 1.16 & 2.50 & 47.00 & 45.00 & 49.67 \\
\hline $\mathbf{T}_{\mathbf{1 0}}$ & 1.16 & 2.60 & 50.00 & 51.00 & 52.88 \\
\hline $\mathbf{T}_{\mathbf{1 1}}$ & 1.19 & 2.76 & 49.66 & 47.33 & 57.23 \\
\hline F-test & $\mathbf{N S}$ & $\mathbf{N S}$ & $\mathbf{N S}$ & $\mathbf{S}$ & $\mathbf{S}$ \\
\hline S. Em $\mathbf{( \pm )}$ & 0.03 & 0.14 & 3.12 & 1.27 & 1.56 \\
\hline C. D. at 5\% & 0.07 & 0.29 & 6.34 & 2.58 & 3.16 \\
\hline
\end{tabular}

Table.2 Effect of different levels of NPK, Zinc and NSC on soils chemical properties after harvest Maize crop

\begin{tabular}{|c|c|c|c|c|c|c|c|}
\hline Treatment & $\begin{array}{c}\mathrm{pH} \\
(\mathbf{1}: 2) \\
\end{array}$ & $\begin{array}{c}\mathrm{EC} \\
\left(\mathbf{d S m}^{-1}\right)\end{array}$ & $\begin{array}{l}\text { OC } \\
(\%)\end{array}$ & $\begin{array}{l}\text { Nitrogen } \\
\left(\mathrm{kg} \mathrm{ha}^{-1}\right)\end{array}$ & $\begin{array}{l}\text { Phosphorus } \\
\left(\mathrm{kg} \mathrm{ha}^{-1}\right)\end{array}$ & $\begin{array}{c}\text { Potassium } \\
\left(\mathrm{kg} \mathrm{ha}^{-1}\right)\end{array}$ & $\begin{array}{c}\text { Zinc } \\
(\mathbf{p p m})\end{array}$ \\
\hline$T_{0}$ & 7.07 & 0.18 & 0.50 & 274.70 & 67.49 & 154.70 & 0.98 \\
\hline $\mathbf{T}_{1}$ & 6.88 & 0.19 & 0.46 & 291.10 & 24.67 & 175.06 & 1.21 \\
\hline $\mathbf{T}_{2}$ & 6.70 & 0.19 & 0.43 & 284.16 & 27.91 & 184.88 & 0.99 \\
\hline $\mathbf{T}_{3}$ & 7.02 & 0.19 & 0.6 & 272.18 & 28.06 & 174.86 & 1.35 \\
\hline $\mathbf{T}_{4}$ & 6.81 & 0.18 & 0.53 & 284.99 & 28.02 & 179.05 & 1.36 \\
\hline $\mathbf{T}_{5}$ & 6.81 & 0.18 & 0.63 & 264.81 & 28.95 & 183.78 & 1.40 \\
\hline$T_{6}$ & 6.99 & 0.19 & 0.66 & 262.10 & 29.72 & 181.96 & 1.45 \\
\hline $\mathbf{T}_{7}$ & 7.17 & 0.19 & 0.66 & 314.28 & 30.31 & 196.30 & 1.17 \\
\hline $\mathbf{T}_{8}$ & 7.34 & 0.19 & 0.63 & 346.17 & 31.64 & 215.09 & 1.50 \\
\hline $\mathbf{T}_{9}$ & 7.08 & 0.19 & 0.60 & 345.19 & 32.61 & 232.21 & 1.51 \\
\hline$T_{10}$ & 7.29 & 0.18 & 0.63 & 345.77 & 34.38 & 234.28 & 1.54 \\
\hline $\mathbf{T}_{11}$ & 7.65 & 0.19 & 0.6 & 363.13 & 34.61 & 240.05 & 1.61 \\
\hline F-test & NS & NS & $\mathbf{S}$ & $\mathbf{S}$ & $\mathbf{S}$ & $\mathbf{S}$ & $\mathbf{S}$ \\
\hline S. Em ( $( \pm)$ & 0.31 & 0.01 & 0.03 & 6.44 & 0.18 & 2.74 & 0.05 \\
\hline C. D. at $5 \%$ & 0.62 & 0.02 & 0.06 & 13.09 & 0.36 & 5.57 & 0.10 \\
\hline
\end{tabular}


It may be concluded from trial that the different level of NPK, zinc and neem cake in the experiment. Bulk density $\left(\mathrm{g} \mathrm{cm}^{-3}\right)$ the treatment combination $\mathrm{T}_{2} \quad[\mathrm{NPK} @ 0 \%+$ Zinc@50\% + NSC@0\%]. Particle density (g $\mathrm{cm}^{-3}$ ) the treatment combination $\mathrm{T}_{11}$ [NPK@100\% + Zinc@50\% + NSC@50\%], pore space $(\%)$ the treatment combination $\mathrm{T}_{11}$ [NPK@100\% + Zinc@50\% + NSC@50\%], solid space $(\%)$ the treatment combination $\mathrm{T}_{9}$ [NPK@100\% + Zinc@0\% + NSC@50\%] and water retaining capacity $(\%)$ the treatment combination $\mathrm{T}_{11}$ [NPK@100\% + Zinc@50\% + NSC@50\%] was found to be the best, for improvement of the physical properties of soil. It may be concluded from trial that the different level of NPK, zinc and neem cake in the experiment. $\mathrm{pH}$ the treatment combination T8 $[$ NPK@100\% + Zinc@0\%+NSC@0\%], $\mathrm{EC}\left(\mathrm{dSm}^{-1}\right)$ the treatment combination $\mathrm{T}_{9}$ [NPK@100\% + Zinc@0\% + NSC@50\%] and organic Carbon $(\%)$, available nitrogen $(\mathrm{kg}$ $\left.\mathrm{ha}^{-1}\right)$, phosphorus $\left(\mathrm{kg} \mathrm{ha}^{-1}\right)$, potassium $\left(\mathrm{kg} \mathrm{ha}^{-1}\right)$ and zinc (ppm) the treatment combinationT $_{11}[\mathrm{NPK} @ 100 \%$ + Zinc@ $@ 50 \%$ + NSC@50\%], was found to be the best, for improvement of the chemical properties of soil.

\section{Acknowledgement}

Authors are sincerely thankful to Dr. Arun Alfred David and Dr. T. Thomas Head and Associate Prof., Department of Soil Sciences and Agricultural Chemistry, for taking their keep interest and encouragement to carry out the research work at Sam Higginbottom University of Agriculture, Technology and Sciences, SHUATS Allahabad.

\section{References}

Garba, J. and oylinlola, E.Y. (2014). Neem seed cake and inorganic fertilizer amendments for sustained productivity of maize (Zea mays) on Nigerian
Savannah Alf sols.

Jackon, M.L. (1958).Soil chemical analysis. Second edition Indian Reprint, prentice hall of India, New Delhi.498.

Kimdu, S.,Gajbhiye, P. N., Rao, C. and Bheemaiah, G. (2009).Effect of integrated nutrient management on yield attributes, yield, nutrient uptake and economics of growing maize in tamarind-based cropping system. Indian Journal of Dry land Agricultural Research and Development. Vol. 24: 1, pp 81-86.

Mengal, K. and Kirkby, E. A. (2006). Principal of plant Nutrition. $5^{\text {th }}$ edn. Kluwer Academic Publishers, Dordrech.

Mengel, K. and Kirkby, E.A. (1987).Principal of plant nutrition. A Bern Switzerland: International Potash Institute, 452-453.

Olsen, S. R., Cole, C.V., Watnahe, F. S. and Daen, L. A. (1954). Estimate of available phosphorus in soil by extraction with sodium bicarbonate. U.S.Deptt. Agri. ciric.

Shaw, E. and Dean, L.A., (1952). The use of dithizone as an extractant to estimate the zinc nutrient status of soils. Soil sci. 73:341-344.

Singh, S., Sati, A. and Mishra, P., (2010).Soil test based integrated $\mathrm{N}, \mathrm{P}$ and $\mathrm{K}$ prescriptions for yield targets of maize in Mollisols of Uttarakhand. Panthngar Journal of Research. Vol.8: 2, pp 248250.

Srikanth, M., Amanullah, P., Mohamed, M. and Muthukrishnan, P. (2009). Yield and economics of hybrid maize as influenced by plant density and fertilizer levels. Green farming, 2 (4): 2003-2005

Subbaiah, B. V. and Asija, C. L. (1956).A rapid procedure for the estimation of available nitrogen in soil. Current Sciences; 25, 259-260.

Toth, S.J. and Prince, A.L. (1949).Estimation 
of cation exchange capacity and exchangeable $\mathrm{Ca}, \mathrm{K}$ and $\mathrm{Na}$ content of soil by Flame Photometer technique. Soil Sci., 67: 439-445.

Walkley, A. and Black, I. A., (1947). Critical examination of rapid method for determining organic carbon in soils, effect of variance in digestion conditions and of inorganic soil constituents. Soil sci.632:251.

Wilcox, L. V., (1950). Electrical conductivity Am. water work, Assoc. J 42; 775-776. Zinc and Farmyard Manure Legume Res., 33, (4) $295-298$.

\section{How to cite this article:}

Sonu Singh, Arun Alfred David and Tarence Thomas. 2017. Response of Different Levels of NPK, Zinc and Neem Cake on Soil Health Growth and Yield of Maize (Zea mays L.)Var. Ganga 101. Int.J.Curr.Microbiol.App.Sci. 6(7): 194-202. doi: https://doi.org/10.20546/ijcmas.2017.607.023 